\title{
Turismo diante das Tendências de Globalização e Integração Regional: Mercosul (1988-1993)
}

\author{
Jorge Antonio Santos Silva
}

RESUMO: Análise das implicações e efeitos do fenômeno da globalização e regionalização da economia mundial sobre o projcto de integração econômica dos países do Cone Sul, com a formação do Mercosul; e sobre o turismo em particular, buscando verificar como se processa a sua inserção no âmbito do mercado comum e através de indicadores de chegadas e ingressos por turismo internacional na sub-região, no periodo de 1988 a 1993. Avaliação de perspectivas do desenvolvimento do turismo nos quatro paises-membro, a partir da consolidação do Mercosul.

PALAVRAS-CHAVES: Economia e turismo: globalização; integração regional; Mercosul; turismo internacional; indicadores; perspectivas.

ABSTRACT: This article analyses the phenomena of the world economy globalization and regionalization about the economic integration between the nations that build the "Cone Sul" with a formation of the Mercosul, focusing its effects and implications. It also, detaches the Tourism, trying to realize how its insertion in the comon market works throught indicator numbers of international tourism arrivels into the region, during the following period: 1988 to a993. Avaliation of the future tourism development in those four countries, since the Mercosul consolidation.

KEY WORDS: Tourism and Economy; globalization; regional integration; Mercosul; international tourism; indicalors; perspectives.

1. Mestre em Administração. Professor do Curso de Especialização em Turismo da Faculdade de Turismo da Bahia e Gerente de Estudos Econômicos da Bahiatursa.

End. para corresp.: Bahiatursa - Ed. Sede do Centro de Convençōes - Jd. Armação - 41.750-270 Salvador - BA - Brasil. 


\section{Introdução}

As macrotendências em curso na sociedade contemporânea, de globalizaçã da economia mundial c de formação de mercados regionais, através da integração de países em blocos econômicos, marcam a evolução recente e as perspeçaça futuras de povos c nações. Nesse cenário, as inovações tecnológicas aproximas mundo cada vez mais, colocando as nações em contato com a mesma realimam 0 mesmo tempo e em toda a parte. Com isso ocorrem modificacõos rade, ao influenciando as relações internacionais nos âmbitos político e econômicais, redesenhando dinâmica e celeremente a cconomia global e os seus agentes meno, e empresas e consumidores, bem como a estrutura institucional, a partir do próprio papel do Estado nesse contexto de mudanças. Deflagra-se assim uma expressiva expansão da economia de serviços e do comércio internacional, com a eliminac̃a de barreiras e fronteiras, ancorada no respeito ao princípio das quatro liberdades: a livre circulação dos fatores de produção - bens, serviços, pessoas e capitais

Neste estudo, analisam-se as implicações e os efeitos do fenômeno de globalização e regionalização da cconomia mundial sobre o projeto de intregração econômica dos países do Cone Sul, com a formação de um mercado regional - 0 Mercosul; c sobre o turismo em particular, buscando verificar como se processa a sua inserção no âmbito do mercado comum, e através da observação do comportamento evolutivo de indicadores de chegadas e ingressos por turismo internacional na sub-região, no período de 1988 a 1993. Avaliam-sc as perspectivas que se oferecem para a alavancagem do desenvolvimento do turismo nos quatro paísesmembros, a partir da consolidação do Mercosul.

\section{Turismo diante da Globalização e Regionalização da Economia Mundial}

O turismo, conforme Naisbitt (1994), é o scgundo setor globalizado, após os serviços financeiros. A abertura de mercados, o fim das grandes corporações, as inovações tecnológicas na informática e nas telecomunicações, e, principalmente, a expansão da economia de serviços, são componentes do processo de globalização que se constituem em fatores fundamentais para a efetivação de mudanças significativas e conseqüente crescimento da importância do turismo na economia significativial.

Por seu turno, a tendência à regionalização do mercado internacional, conl a formaño dos blocos econômicos, deverá provocar um expressivo incremento do a formação dos blocos economicos, deverá provocar um expressir o increndegárias. turismo intra-regional, pois a supressão de barreiras geográficas e alfandegáraçâl permitindo a livre circulação dos turistas, beneficiará as viagens de menor dur çá suá distância, impactando positivamente sobre a demanda, dado que propiciara sta distribuição de modo mais regular durante o período anual, reduzindo, portanto, efeitos nocivos da sazonalidade. do tão depressa quanto os canais de distribuição. Conforme esse estudioso, udando ta corviços, em acelerada expansão, não opera em contradição ou cresce economiade servi econom da economia de bens. Na verdade, ela funciona como um canal de ass custas dãa para a economia de bens, e o segmento que mais cresce no canal é o distribuiça economistas podem não considerar o lazer como parte da economia, mas lazer. Os esponsável por um enorme volume da distribuição de bens:

a economia de serviços é um canal de distribuição para bens em termos econômicos, e os canais de distribuição mudam mais depressa que os próprios bens ou serviços. (Drucker, 1992).

A importância portanto, assumida pelo mercado de viagens e turismo para economia mundial, com milhões de pessoas viajando, consumindo e promovendo distribuição de bens e serviços por todo o planeta, coloca este mercado numa posição de liderança no comércio internacional, pois representa uma parcela sosiçificativa da geração e circulação da riqueza transacionada no mercado global

Em relação a outros setores econômicos, o turismo apresenta um potencial de crescimento muito mais expressivo:

Enquanto a maioria dos produtos comercializados no mercado internacional estão sujeitos a acordos, taxas, sobretaxas e retaliações, o turismo não sofre limitações significativas, por serem os principais mercados emissores, aqueles paises cujas condiçôes políticas dificultam a existência de restricões para viagens internacionais. (Romera, s.d.)

Além disso, esses mesmos países são os pólos de efervescência e expansão das inovações tecnológicas e de irradiação da tendência globalizante.

Um expressivo e crescente número de países reconhece que o interesse por experimentar ambientes e culturas diferentes representa uma oportunidade econômica, sendo o turismo considerado uma alternativa real tendo em vista a aceleração do desenvolvimento econômico desses pasíses.

Através de suas ligações com outros setores econômicos, como a pesca, a agricultura e a manufatura, o turismo contribui com uma porcentagem ainda [mais significativa] para [a formação do] peril econômico de cada Estado.

(Naisbitt,1994)

Segundo dados da Organização Mundial do Turismo (OMT, 1993), o de 500 to das chegadas por turismo internacional no mundo, significou um total \$ milhões de turistas e um volume de ingressos da ordem de US $\$ 304$ bilhões, fente situaram-se em primeiro lugar entre os grupos de exportação mundial, à petróleo, veículos automotivos e equipamentos eletrônicos, representando 
$8,6 \%$ das exportações mundiais de mercadorias e $30 \%$ das exportações de serviços
comerciais. No período $1990 / 93$, o número de chegadas por turismo int apresentou uma taxa de crescimento de $3 \%$ a.a., enquanto os ingressos regis rara incremento de 5,3\% a.a. Com a expectativa de crescimento das viagens intermarn onais a uma taxa média de 3 a 3,5\% para $1990 / 95$ e de 4 a $5 \%$ para 1996/200 atingido o total de 534 milhões de turistas em 1995 e de 661 milhões no

Apesar desses números, e do fato que para muitos países o turismo 2000. constitui na maior fonte de renda e no setor mais forte no financiamento de suas economias, a "reboque" do setor de serviços, é pouco citado, e até mesmo ignorado nos tratados ou acordos visando a constituição de mercados regionais formais, os nos tratados ou acordo
blocos econômicos.

A razão dessa precária explicitação do turismo nos projetos de integração econômica, deve- se, a que o turismo se apresenta como

uma indústria de múltiplos componentes, da qual muitas partes estão inexíricavelmente associadas a outro setor econômico: as empresas de aviação ao transporte, as lojas de souvenirs, os stands de concessionárias e os restaurantes ao comércio varejista ou aos serviços, e os hotéis e outras acomodaçōes ao desenvolvimento comercial.

(Naisbitt, 1994)

Em outra explicação, Naisbill (1994) cita o artigo Broadening the Mind: a Survey of world Travel and Torism ("The Economist", 23 de março de 1991):

A importância do setor turismo é de difícil compreensão, por peio meros tres razōes. Primeira, não existe uma definição aceita do que constitui essa inıúsustria; qualquer definição corre o risco de superestimar ou subestimar a atividade econômica. Segunda o turismo é um negócio em que muitas atividades (como a dos guias ie furismo e dos vendedores de souvenirs) e receitas (gorjetas) se prestam bem aos praticantes da economia informal. Nos paises com controle do câmbio exterior (que è sempre contornado), todas as cifras oficiais sobre os gastos no estrangeiro estāo erradas. Terceira, o turismo internacional sofre de diferenças espantosas nos dados de dí́erentes paises.

Consideradas essas observações, é incontestável a importância do mercado de viagem e turismo para a ecomonia mundial, principalmente diante das tendências visualizadas no processo de globalização, as quais, tomadas de Naisbitt (1994) são as seguintes:

- as empresas de aviação já se deparam e interagem num contexto de economia global. A desregulamentação da indústria e a privatização de empresas de aviação estatais são práticas cada vez mais comuns aos mercados intercado, da nais, observando o padrão de maior facilidade de entrada no mercado mo. abolição de quotas de capacidade e da fixação de preços baseada no marketing, Nesse processo, as empresas de aviação estão selando acordos de marketin uendo açoes e formando alianças estratégicas por meio de fusões, jointvendres e parcerias (compartilhamento de códigos e co-promoções). O pacto ven "céus abertos" vem revogar as restrições governamentais sobre rotas e de "ruêencias de vôos internacionais, introduzindo o conceito do país sem frequêen na indústria da aviação, tendendo a superar acordos bilaterias em pró fronte um acordo global único;

través dos acordos de cooperação entre as linhas aéreas internacionais e dos atrvestimentos extcrnos $\mathrm{em}$ hotéis $\mathrm{c}$ atrações turísticas, a indústria do turismo que já é uma indústria global pelo expressivo numero de pessoas que viajam internacionalmentc - tende a se globalizar cada vez mais, pois, a desregulamentação da indústria da aviação será seguida por políticas mais liberais para com os investimentos externos no turismoe nas indústrias correlatas;

- cerca de 430 milhões de cidadões do Leste Europeu e da ex-União Soviética adquiriram a liberdade de viajar, representando uma população superior à de toda a Europa Ocidental;

- as mudanças das economias da China e da India, de centralizadas para de livre mercado; esses países abrigam $38 \%$ da população mundial;

- a retirada dos controles de fronteira entre as doze nações da CEE;

- a criação da maior área de livre comércio do mundo, composta de Canadá, EUA e México, englobando 370 milhões de consumidores e uma producão total próxima a US\$ 7 trilhões (o Mercosul representa cerca de 200 milhões de consumidores c US\$ 630 bilhões de renda);

- a mudança de atitude para com o turismo, antes considerado um privilégio de poucos, a elite abastada, agora como direito de todos;

- as fronteiras entre os Estados-nação tornaram-se mais porosas, com as democracias tradicionais ou os países recém-democratizados reconhecendo a liberdade de locomoção como um direito humano básico;

- a infra-estrutura global de transportes está se tornando um caminho ininterrupto e interconectado para todas as partes do mundo;

- Obaratean

de conamento das viagens aéreas torna-as mais acessíveis a um maior número consumidores, ampliando os limites dos viajantes;

- a elevacir

polenacão dos padrões de vida, as novas tocnologias de transporte e a curio

a claciaisviajantes sinalizam uma permanente viabilidade do turismo-emnível global

a classe abastada está crescendo c procisará gastar , porque não com viagens e lazer? 
- com a abertura das fronteiras, o amadurecimento e prosperidade da população a promoção do governo, da iniciativa privada e dos educadores, as pessoas eção, cada vez mais realizando viagens, c o mercado de viagens e turismo corresstão com planos de viagens e condições coerentes com qualquer orçamentonde situação: idosos, famílias com crianças, solteiros e solteiros com crion ou inválidos, mulheres acima dos quarenta anos, e outros. Para qualquer crianças, (ica diferenciadora existo um pacote ou programa delin a delineado para atender às necessidades específicas de cada segmento.

Está-se vivendo uma época marcada por comunicaçõcs internacionais mais intensas, maior liberdade de locomoção, comércio internacional mais ampliado, por maior volume de investimentos de extrema mobilidade entre as fronteiras internacionais. Numa época com esse contorno, o turismo ć a força que unificará a aldeia global, sendo reconhecido pelos protagonistas do mercado internacional o seu elcvado potencial econômico c a necessidade de superação ou climinação de barreiras ao seu crescimento (Naisbitt, 1994)

Além da importância econômica que se reveste em todo o mundo, o turismo incorpora-se às necessidades fundamentais do ser humano, que através do lazer recompõc o equilíbrio emocional, recupera a capacidade de interrelacionamento pessoal e, ao interagir com novas culturas, habilita-se mais facilmente ao processo de integração entre as nações.

Aidentificação com um grupo é crucial para o sentido de identidade de cada um. À medida que a economia mundial se integra e que a sociedade global se torna cada vez mais homogênea, as necessidades dos individuos de preservar um sentido de identidade em um mar de homogeneizacão se fortalece. Por conseguinte, as pessoes se tornam [cada vez mais] propensas a viajar, enquanto procuram preservar um sentido de continuidade e de filiação a um grupo

(Naisbitt,1994)

Assim é que a maior indústria - o turismo - é impelida pelas decisões individuais, manifestando-se também aqui, o paradoxo global concebido por Naisbitt: quanto mais integrado se torna o mundo, mais intensa é a busca de diferenciação das experiências por parte dos indivíduos - os protagonistas menores decidem. Quanto maior e mais competitivo se torna o turismo, mais atrativas para os turistas se tornam as culturas autênticas, não padronizadas ou mercadizadas, mas caracterizadas como nichos ou mercados competitivos na economia global.

O mercado turístico internacional tem acompanhado a dinâmica do mercado mundial no sentido da expansão e crescente competição entre um número cadais vez maior de destinos turísticos, em relação a uma demanda cada vez consciente c exigente por qualidade e diversificação de produtos e serviços.

Nesse contexto, as principais tendências e condicionamentos do meguntes: turístico internacional são, conforme Trigueiros (1994), os seguln busca de melhor qualidade nas instalações e na prestação de serviços;

existência de um ambiente não degradado, indicando a importância dos recursos naturais e culturais para o desenvolvimento do turismo;

escalonamento das férias escolares, levando a um aumento do número de viagens, embora com a redução na permanência no destino;

procura de produtos turísticos diferenciados, voltados para as inquietudes dos consumidores no terreno da cultura e do ócio;

- surgimento de destinos diferentes, competitivos, oferecendo vantagens como redução de custos.

A promoção e a comercialização do produto turístico de países menos desenvolvidos, em razão da intensa concorrência e dos requisitos de competitividade exigidos pelo mercado mundial, dependem de uma ação global e eficaz de planejamento e coordenação, num esforço integrado de governo e iniciativa privada. De um lado, o governo possui a estrutura, o aparato institucional e os recursos necessários para a implantação de infra-estrutura básica e urbana no pólo turístico, criando as condições de atratividade para a captação de investimentos particulares e financiamentos de organismos internacionais de desenvolvimento. De outro, a iniciativa privada tem condições de promover ações necessárias ao desenvolvimento do produto turístico e a sua comercialização, visando concretização do mesmo como um produto atraente e cativador de fluxos turísticos internacionais.

O sucesso residirá na cooperação entre os dois centros decisórios, o que espera-se ocorra de fato, no projeto de integração econômica entre os países do Cone Sul, objetivando a afirmação competitiva do produto turístico integrado do Mercosul, romposto pelo conjunto de atrativos tradutores dos pontos fortes e de diferenciação dos seus parceiros, no mercado turístico mundial.

\section{Inserção do Turismo no Mercosul (1988-1993)}

A importância do turismo para os países latino-americanos, e em especial para os do Cone Sul, é relativa, dependendo das peculiaridades e características individuais de suas economias. Esses traços particulares referem-se a uma série de variáveis: população, PIB, exportações e importações, dentre outras; inserindo-se o turismo, como "... parte integrante de um sistema maior" (Lage, 1993).

$O$ processo de integração do Cone Sul, no âmbito turístico, teve origem antes do foprio Mercosul, quando, por iniciativa da Comissão Latino-Americana para o Turismo, associação Latino-Americana de Integração (Aladi), e diante da Primeim de impulsionar o turismo nos países da América do Sul, decidiu-se criar a ra sub-comissão experimental, denominada Comissão de Turismo da América do 

Sul (Cotasul), integrada pelosórgãos oficiaisde turismo dos dez paises sul-americanos, para
começar a forjar uma imagem de integração.

Em julho de 1991, de acordo com Schlüter \& Winter (1993), os órgãos oficiais de turismo da Argentina, Brasil, Paraguai e Uruguai, em reunião realizad em Montevidéu, Unuguai, decidiram formalizar um acordo para realizar açada conjuntas na área do turismo, se dispondo a:

- instituir um passc aéreo promocional entre e para os quatro paises;

- criar uma entidade comum para o desenvolvimento das ações futuras no plano turístico sob a denominação de Mercado Comum do Turismo (Mercotur);

- desenvolver ações conjuntas para promover a sub-região como um único destino turístico, participando de feiras e exposições internacionais;

- solicitar a inclusão do capitulo turismo como uma das comissões do Mercosul

- assumir o compromisso de levar a suas respectivas chancelarias o acordo, com 0 propósito de dar a conhecer este projeto aos ministros de relações exteriores e solicitar que scja transmitido aos respectivos mandatários, a fim de que, no futuro, nos encontros presidenciais, figure na agenda o tema turismo como elemento de integração e fonte de importantes recursos econômicos para cada um dos paises;

- convidar c incentivar o setor privado: operadores turísticos, agentes de viagens, hoteleiros, transportadoras, companhias aéreas, restaurantes $\mathrm{c}$ outras entidades c/ou prestadores de scrviços ligados ao amplo espectro da "indústria turística", a participar ativamente de execução do plano promocional, contribuindo desta maneira para o desenvolvimento setorial.

Encaminhou-sc, em pararelo, um comunicado aos representantes das linhas aércas de bandcira de cada pais, expressando o propósito dos respectivo governos de criar um elemento promocional visando aumentar o tráfego turístico para a região, sendo necessário a ação complementar das companhias aéreas, sugcrindo-se às mesmas algumas medidas de apoio ao projeto:

- incluir nas tarifas aéreas o custo do passe turístico;

- rever os níveis das tarifas intrac extra-regionais, pouco atrativas pelo elevado custo;

- criar uma tarifa mais atrativa, permitindo ao passageiro descer em mais de um país sem implicar em custo adicional;

- eliminar excessivas restrições impostas ao passageiro ao adquirir tarifas promocionais; estudar um pool entre linhas aéreas, visando reali

linhas e incrementar o tráfego nas rotas regionais

criar um espaço diferenciado nos counters dos aeroportos, para propiciar uma atenção preferencial ao portador do passe turístico;

ampliar a margem permitida no peso da bagagem dos portadores do passe turístico.

Desse modo, com o turismo ganhando uma maior dimensão no fórum regional das articulações pró integração, constituiu-se formalmente uma Comissão de Turismo dentro do Mercosul, que vem trabalhando na definição de uma política turística integrada para a região, bem como na harmonização de políticas econômicas que influenciam no desenvolvimento do turismo em cada país-membro.

A IX Reunião Especializada de Turismo do Mercosul, realizada em junho de 1994, em San Juan, na Argentina, procurou atualizar os diversos pontos em discussão, dos quais se destacam os seguintes:

linhas aéreas: não se chegou a uma definnição, que permita a efetividade do passe turístico Mercosul Air Pass (MAP);

programa integrado de marketing: decidida a reativação da Comissão de Marketing, existindo alguns temas para análise e definição de políticas:

- ações conjuntas no mercado asiático,

- captação de eventos no âmbito latino-americano, no interesse de desenvolver o turismo de congressos e convenções,

- elaboração de uma proposta operativa que contribua para dinamizar os fluxos turísticos intra-regionais na baixa temporada;

Egisiação turistica:

- manter a vigência e validade dos documentos de cada Estado Parte para traslado dentro dos países do Mercosul, sendo os mesmos:

- para a República Argentina - Libreta de Enrolamento, Libreta Cívica, Documento Nacional de Identidade, Cédula de Identidade da Politica Federal e Passaporte:

- para a República Federativa do Brasil - Cédula de Identidade expedida por cada Estado com validade nacional e Passaporte; 
- para a República do Paraguai c a República Oriental do Uruguai - Cédula de
Identidade e Passaporte;

- sugeriu-se que a Argentina reduza paulatinamente o número de documento identificatórios e que o Brasil centralize a emissão do documento de identidade
com características comuns em nível nacional;

- recomenda-se a progressiva compatibilização das características dos passaportes, quer seja para uso no âmbito do Mercosul, quer para terceiros países, em consonância com as recomendações internacionais vigentes;

- foi acordado que não se deveria substituir os passaportes atualmente em vigência no caso de viagem para terceiros países.

Nota-se, que em relação aos aspectos institucionais c legais, o Mercosul está bem articulado, e apesar das dificuldades de percurso - principalmente as relacionadas com a heterogeneidade das cconomias e sociedades dos países-membros e com a dificuldade de harmonização das políticas macroeconômicas - a vontade política cxercida por parte dos governos desses países, apesar do imediatismo na condução do processo, conseguiu levar o projeto avante. A partir de $1^{\circ}$ de janeir de 1995 o Mercado Comum do Cone Sul será uma realidade, assumindo personalidade jurídica de direito internacional e de direito interno, podendo assim realizar negociação de acordos com terceiros países ou organismos internacionais.

Viu-se também, que antes mesmo de alcançar o presente estágio, já a partir de 1991, o advento do Mercosul estimulou um crescimento do comércio exterior entre os seus países-membros, registrando desempenhos positivos no volume de suas exportações e importações de mercadorias, comportamento que tende a se reforçar com a vigência oficial de uma zona de livre comércio e uma união aduaneira.

Com relação às perspectivas do processo de integração no que concerne ao turismo, passa-se a analisar, comparativamente, alguns indicadores setoriais e a evolução do fluxo turístico intra-regional, no periodo 1988/93, visando levantar o perfil desse mercado dentro do Mercosul, e deste $\mathrm{cm}$ relação às Américas, aos mercados extra-Américas c ao mercado mundial; c avaliar o potencial que 0 mercado turistico representa para os parceiros do Cone Sul, diante das tendências globalizantes do turismo internacional.

Algumas proocupações se colocam de imediato, em relação a condições e requisitos a serem supridos pelo Mercosul, para oêxitodo projeto de integraç̃̃o no campo do turismo. Tais preocupações, suscitadas por Milone (1993), são as seguintes:

- capacidade de gerar as condições de paridade e estabilidade cambial que permitam a vinda de turistas estrangeiros para a região, carreando um fluxo perescom crescente de ingressos
número de visitantes; capacidade de ofertar conforto e segurança interna aos turistas estangeiros, capacido este vinculado à existência nos países-membros de sociedades econômias social e politicamente equilibradas;

capacidade de criar um produto atrativo, com pólos turísticos que motivem os - caristas estrangeiros a visitarem indistintamente os quatro países, inserindo-se assim o mercado turistico regional de forma competitiva na oferta internaciona de bens e serviços turísticos.

Antes de enfocar a análise do desemenho evolutivo do fluxo e dos ingressos por turismo internacional nos países do Mercosul, período 1988/93, aborda-se a representatividade de cada país-membro em alguns indicadores específicos, no ano de 1992, a saber: ingressos turísticos, PNB, exportações e capacidade receptiva/ oferta de aposentos para hospedagem.

A Tabela 1 relaciona os ingressos por turismo internacional dos paises do Mercosul com os respectivos PNBS, com base em dadosde 1992. Nesse ano, do toal de ingressos turísticos do Mercosul, a Argentina responde por cerca de $63 \%$, o brasil por $26 \%$, enquanto Paraguai e Uruguai juntos corresponderam a quase $11 \%$.

Quanto à participação de cada país no PNB do Mercosul, a situação invertese: 0 Brasil representou em torno de $61 \%$ do total, a Argentina cerca de $36 \%$, ficando Paraguai e Uruguai com uma participação conjunta próxima de $3 \%$.

$\mathrm{O}$ exame de relação ingressos turísticos/PNB indica para o Brasil a menor representatividade do turismo na renda nacional, entre os parceiros do Mercosul, ou seja, $0,3 \%$. Esta relação situou-se em $1,4 \%$ para a Argentina, 2,4\% para 0 Paraguai e 3,4\% para o Uruguai, e em $0,8 \%$ para o conjunto do Mercosul, em razão da posição desfavorável do Brasil nesse indicador.

Os ingressos por turismo internacional do Mercosul representaram em $1992,5,9 \%$ do total dos ingressos turísticos das Américas, 2,3\% dos ingressos da região Extra-Américas e 1,7\% do total mundial. Quando ao PNB, a participação do Mercosul nas regiões comparadas foi de $8,2 \%, 4 \%$ e $2,7 \%$, respectivamente. A relação ingressos/PNB para as Américas situou-se em 1,1\%, para a região ExtraAméricas em $1,4 \%$ e para o Mundo $\mathrm{cm} 1,3 \%$.

Nesse mesmo ano, a participação dos ingressos por turismo internacional no total das exportações doMercosul ficou próxima de $10 \%$, também influenciada pela posição brasileira, onde os ingressos turísticos significaram menos de $4 \%$ das exportações, enquanto para Argentina, Paraguai e Uruguai esta relação foi notadamente superior, situando-se em $25 \%, 23 \%$ e $22 \%$, respectivamente. $\mathrm{Na}$ América do Sul, a relação ingressos/exportações correspondeu a $8 \%$, nas Américas $11 \%$ e no Mundo a $8 \%$ (Tabela 2).

A Tabela 3 demonstra a relação do turismo com o comércio internacional nas Américas e no Brasil, no período 1988/92. Enquanto os ingressos por turismo internacional nas Américas representaram nesse período em torno de 9 a $11 \%$ das suas portações, noBrasil significaram entre 4 e 5\%. As exportações brasileiras respondem turistica de $5 \%$ das exportações americanas no período, enquanto os ingressos uristicos no Brasil corresponderam a $2 \%$ do total dos ingressos das Américas. 
No que diz respeito à capacidade receptiva, medida pelo número de unidades habitacionais (UHs) disponíveis para hospedagem, em 1992, a Tabelo mostra que a Argentina, com 90 mil UHs, representou 33\% da capacidade tola 4 Mercosul, ocupando o $17^{\circ}$ lugar no ranking mundial, enquanto o Brasil, cotal do mil UHs, respondeu por 51\% da oferta do Mercosul (269 mil UHS), $13^{\mathrm{a}}$ posição no ranking mundial. Até o $40^{\circ}$ lugar do ranking mundial do ando a 1992, não se registra a presença de Paraguai e Uruguai, não sendo ano de identificar a oferta de UHs dos mesmos. A capacidade receptiva do Merivel correspondia, nesse ano, a $6 \%$ da oferta de UHs das Américas, $4 \%$ da região Extral Américas e $2 \%$ do total mundial.

TABELA 1 - INGRESSOS POR TURISMO INTERNACIONAL E PRODUTO NACIONAL BRUTO DOS PAISES DO MERCOSUL, EM RELACÃO ÀS AMÉRICAS E AO MUNDO - 1992 (em US\$ milhöes)

\begin{tabular}{lccccc}
\hline Pais/Regiäo & $\begin{array}{l}\text { Ingressos } \\
\text { (A) }\end{array}$ & $\begin{array}{l}\text { Part. } \\
\text { s/lngr. \% }\end{array}$ & \multicolumn{1}{c}{$\begin{array}{l}\text { PNB } \\
\text { (B) }\end{array}$} & \multicolumn{1}{c}{$\begin{array}{l}\text { Part. } \\
\text { s./PNB \% }\end{array}$} & $\begin{array}{l}\text { Part. } \\
\text { A/B \% }\end{array}$ \\
\hline Argentina & 3.090 & 62,66 & 224.522 & 35,69 & 1,38 \\
Brasil & 1.307 & 26,51 & 386.970 & 61,51 & 0,34 \\
Paraguai & 153 & 3,10 & 6.369 & 1,01 & 2,40 \\
Uruguai & 381 & 7,73 & 11.218 & 1,78 & 3,40 \\
\hline Mercosul & 4.931 & 100,00 & 629.079 & 100,00 & 0,78 \\
\hline \multicolumn{5}{c}{ MERCOSUL/REGIĀO \% } \\
\hline Américas & 83.552 & 5,90 & 7.689 .000 & 8,18 & 1,09 \\
Extra-Américas & 214.301 & 2,30 & 15.767 .000 & 3,99 & 1,36 \\
Mundo & 297.853 & 1,66 & 23.456 .000 & 2,68 & 1,27 \\
\hline Fonde: OMT
\end{tabular}

Fonte: OMT.

TABELA 2 - INGRESSOS POR TURISMO INTERNACIONAL EM 1992 (como \% de Exportaçöes e PNB)

\begin{tabular}{lcc}
\hline Pals/Regiåo & Part./Exp \% & Part/PNB \\
\hline Argentina & 25,3 & 1,4 \\
Brasil & 3,6 & 0,3 \\
Paraguai & 23,3 & 2,4 \\
Uruguai & 22,4 & 3,4 \\
\hline Mercosul & 9,7 & 0,8 \\
\hline América do Sul & 8,3 & 0,9 \\
\hline Américas & 11,3 & 1,1 \\
\hline Mundo & 8,2 & 1,3 \\
\hline
\end{tabular}

Fonte: OMT.

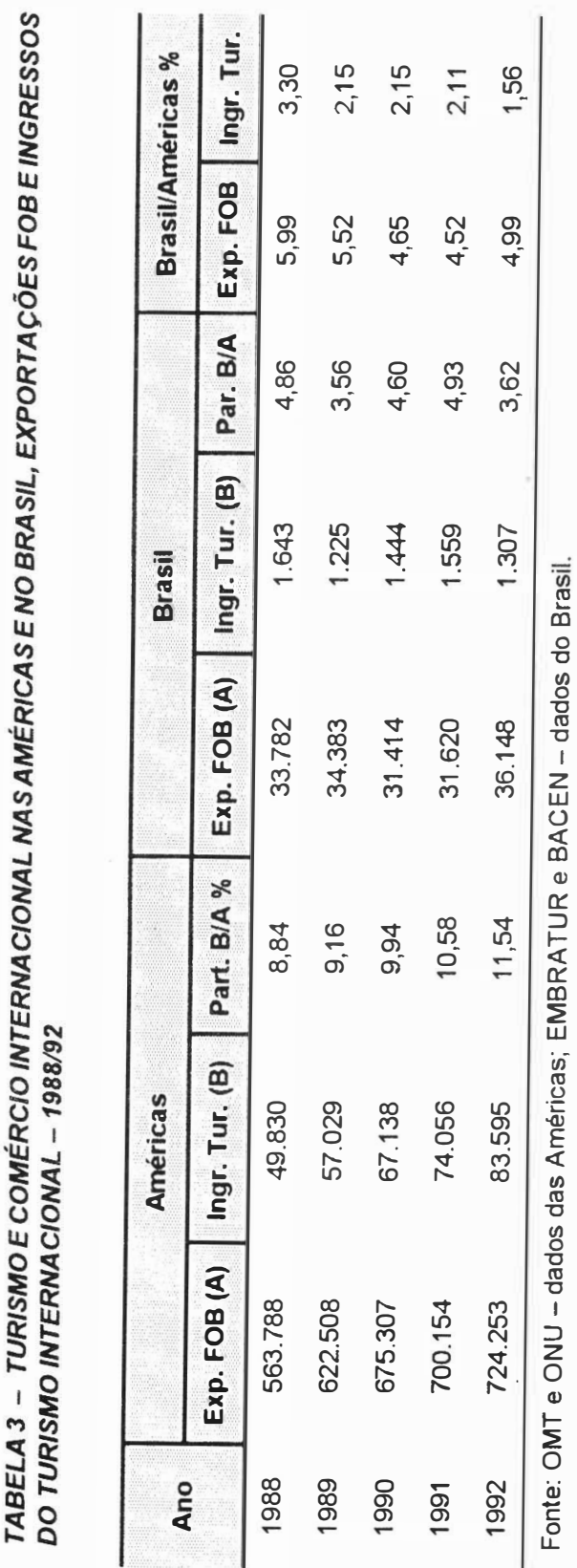


TABELA 4 - CAPACIDADE RECEPTIVA - 1992

(em $n^{\circ}$ de Unidades Habitacionais - UHs)

\begin{tabular}{l|c|c|}
\hline \multirow{2}{*}{ País/Regiāo } & & \\
\hline & em $\mathbf{1 . 0 0 0}$ & No UHs \\
\hline Argentina (a) & 90 & Part. \% \\
Brasil (b) & 138 & 33,46 \\
\hline Mercosul (c) & 269 & 51,30 \\
\hline & MERCOSULREGIĀO \% & 100,00 \\
\hline Américas & 4.483 & 6,00 \\
\hline Extra-Américas & 6.840 & 3,93 \\
\hline Mundo & 11.323 & 2,38 \\
\hline
\end{tabular}

Fonte: OMT.

(a) $17^{\circ}$ no RK mundial.

(b) $13^{\circ}$ no RK mundial.

(c) Até $040^{\circ}$ lugar do RK mundial não aparecem Paraguai e Uruguai.

Nota-se que o Brasil, em termos absolutos e quantitativos, encontra-se na dianteira em relação aos seus parceiros do Mercosul, posição esta bastante relativizada, em razão da situação desfavorável que apresenta quando considerados os aspectos qualitativos relacionados ao desempenho do turismo internacional. Nesses aspectos, os seus parceiros levam vantagem, resultando evidente uma maior participação e importância do turismo em suas economias, e manifestando-se a liderança da Argentina no turismo intra-regional do Cone Sul.

$\mathrm{Na}$ Tabela 5 indica-se a evolução e a distribuição das chegadas por turismo internacional nos paises do Mercosul, entre 1988 e 1993. Dos quatro paísesmembros, apenas o Brasil registra taxa anual negativa de crescimento, de $-1 \%$, caindo de modo acentuado a sua participação no fluxo turístico internacional do Mercosul, de $34 \%$ em 1988 para $21 \%$ em 1993.

A Argentina, no mesmo periodo, apresenta uma taxa de crescimento de $11 \%$ a.a., com sua participação no Mercosul aumentando de $41 \%$ para $46 \%$ entre 1988 e 1993. O fluxo turístico internacional no Paraguai cresceu a uma taxa próxina de $8 \%$ a.a., ficando estabilizada a sua participação no Mercosul em um patamar pouco superior a 5\%. Já o Uruguai registrou a maior taxa anual de crescimento no período, de $15 \%$, e a maior elevação da participação no Mercosul, passando de $20 \% \mathrm{em} 1988$ para $27 \%$ em 1993.

As taxas de crescimento anuais do número de chegadas por turismo internacional para as regiões comparadas, no mesmo período, situaram-se em $8 \%$

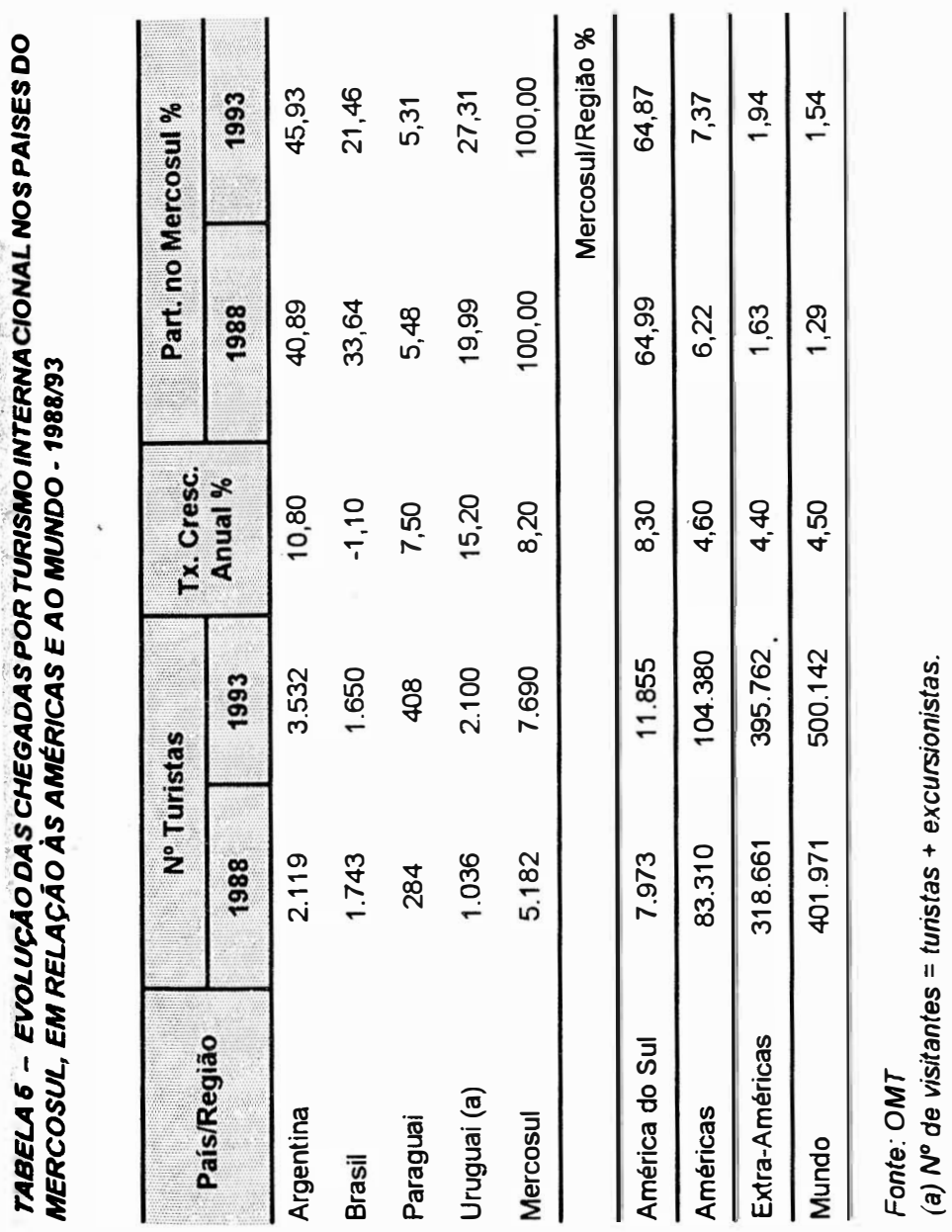


para a América do Sul e entre 4 e 5\% para as regiões das Américas, Extra-Américas e Mundo. A participação do Mercosul no fluxo turístico internacional dessas regiões ficou estabilizada em $65 \%$ na América do Sul, elevando-se de $6,2 \%$ para $7,4 \%$ nas Américas, de $1,6 \%$ para $1,9 \%$ na região Extra-Américas e de $1,3 \%$ para $1,5 \%$ no Mundo, entre 1988 e1993.

A Tabela 6 apresenta um quadro sirnilar, de referência à evolução distribuição dos ingressos por turismo internacional nos países do Mercosul, no período 1988/93. Também neste indicador, o Brasil registra o pior desempenho da sub-região, com uma taxa negativa de crescimento no período, em torno de $-3 \%$ a.a., e uma queda significativa da sua participação no Mercosul, de $63 \% \mathrm{em} 1988$ para $25 \%$ em 1993. Dentre as causa que podem ser indicadas para o desempenho negativo do turismo internacional no Brasil, no periodo analisado, elencam-se as que seguem;

- inexistência de uma estratégia de marketing de longo prazo, em escala internacional;

- redução dos investimentos em promoção no exterior, aproximando-se de zero em 1989 , não ultrapassando a casa de US\$ 1,5 milhão nos últimos anos; enquanto os mercados concorrentes investiram efetivamente no marketing dos seus produtos (mais de US\$ 30 milhões nos casos do México e Porto Rico, em 1993);

- deteriorização da imagem do Brasil no exterior, com a veiculação na mídia internacional de notícias sobre a falta de segurança e violência no Rio de Janeiro, principal destino e portão de entrada dos turistas estrangeiros no país;

- reduzidos investimentos governamentais e conseqüente deficiência na infraestrutura adequada ao atendimento do turismo;

- desestabilização crônica da economia nacional, inibindo o potencial investidor;

- enfraquecimento das relações institucionais entre as diferentes esferas de governo, particularmente quanto à definição e vontade política, fator indispensável ao desenvolvimento do turismo no país.

A Argentina registra uma situação diametralmente oposta, com uma taxa de crescimento anual no periodo, em torno de $42 \%$, observando um aumento expressivo da sua participaça no total dos ingressos turísticos do Mercosul, de $24 \% \mathrm{em}$ sivo da sua participação no
1988 para $64 \%$ em 1993.

O Paraguai cresceu a uma taxa de $10 \%$ a.a., caindo a sua participação no Mercosul, de 4 para $3 \%$, enquanto o Uruguai experimentou um desempento, positivo no periodo, apresentando uma significativa taxa anual de crescíment, em próxima de $17 \%$, com a sua participação no Mercosul permanecendo estável, en torno de $8 \%$

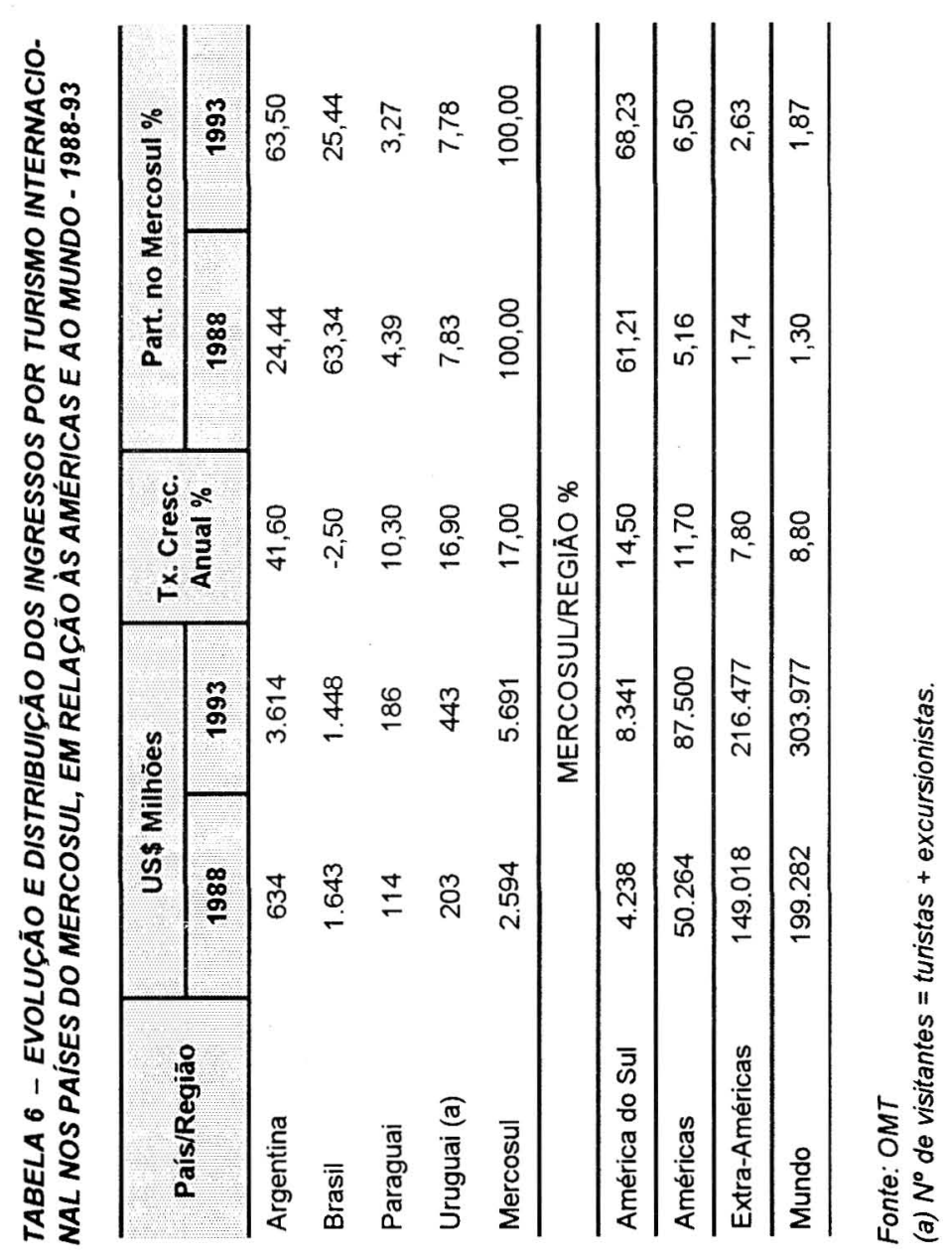


As taxas anuais de crescimento dos ingressos por turismo in ternacional para as regiões comparadas, situaram-se em cerca de $15 \%, 12 \%, 8 \%$ e $9 \%$, respect para mente, para a América do Sul, as Américas, a região Extra-Américas esectivaA participação do Mercosul no total dos ingressos turísticos dessas regiõ Mundo. ing respectivamente, de 61 para $68 \%$; de 5,2 para $6,5 \%$; de 1,7 para $2,6 \%$; e de 1,3 para $1,9 \%$, entre 1988 e 1993

Nas Tabelas 7 e 8, indicam-se os dados anuais relativos às chegadas e ao ingressos por turismo internacional nos países do Mercosul, no período 1988/92 permitindo a observação mais detalhada da evolução desses indicadores e também da sua distribuição entre os quatro países membros. Comparando-se essas duas tabelas, constata- se, em relação ao Brasil, o crescimento do número de chegadas em 1992, comparado com 1991, acompanhado por um decréscimo dos ingressos turísticos derivados. Isto pode ser explicado, conforme Lage (1993), como conseqüência da verificação isolada ou conjunta dos seguintes fatores:

- o gasto médio per capita dos turistas diminuiu, ou seja, consumiram menos em hospedagem, alimentação e compras, uma vez que o transporte não é considerado na despesa;

- a permanência média dos turistas, expressa em número de dias, diminuiu;

- o gasto médio per capita e a permanência média diminuiram conjuntamente, ou seja, em média, a demanda do turismo pode ter reduzido seus gastos e ao mesmo tempo diminuido o tempo de duração de suas viagens;

- os preços relativos no Brasil, expressos em dólar, estando mais elevados, dificultam a aquisição de bens e serviços por parte dos turistas, mesmo quando vindos em maior número;

- o perfil dos turista, quando à procedência, vem se alterando no período, significando que o fluxo intra-regional de turistas para o Brasil tem sido proporcionalmente maior que ofluxo extra-regional, refletindo no menor poder aquisitivo do total dos visitantes.

\section{Turismo Intra-Regional do Mercosul}

As Tabelas 9 a 12 , demonstram, também para o período 1988/92, os dados relativos às chegadas por turismo internacional procedentes do Mercosul, para cada país-membro, possibilitando a avaliação do fluxo intra-regional e a posição deste em relação ao segmento extra-regional, em cada parceiro do Cone Sul. ${ }^{2}$

2. Não se encontram disponiveis, para o ano de 1993, os dados referentes às chegadas por turismo internacional por pais de destino.

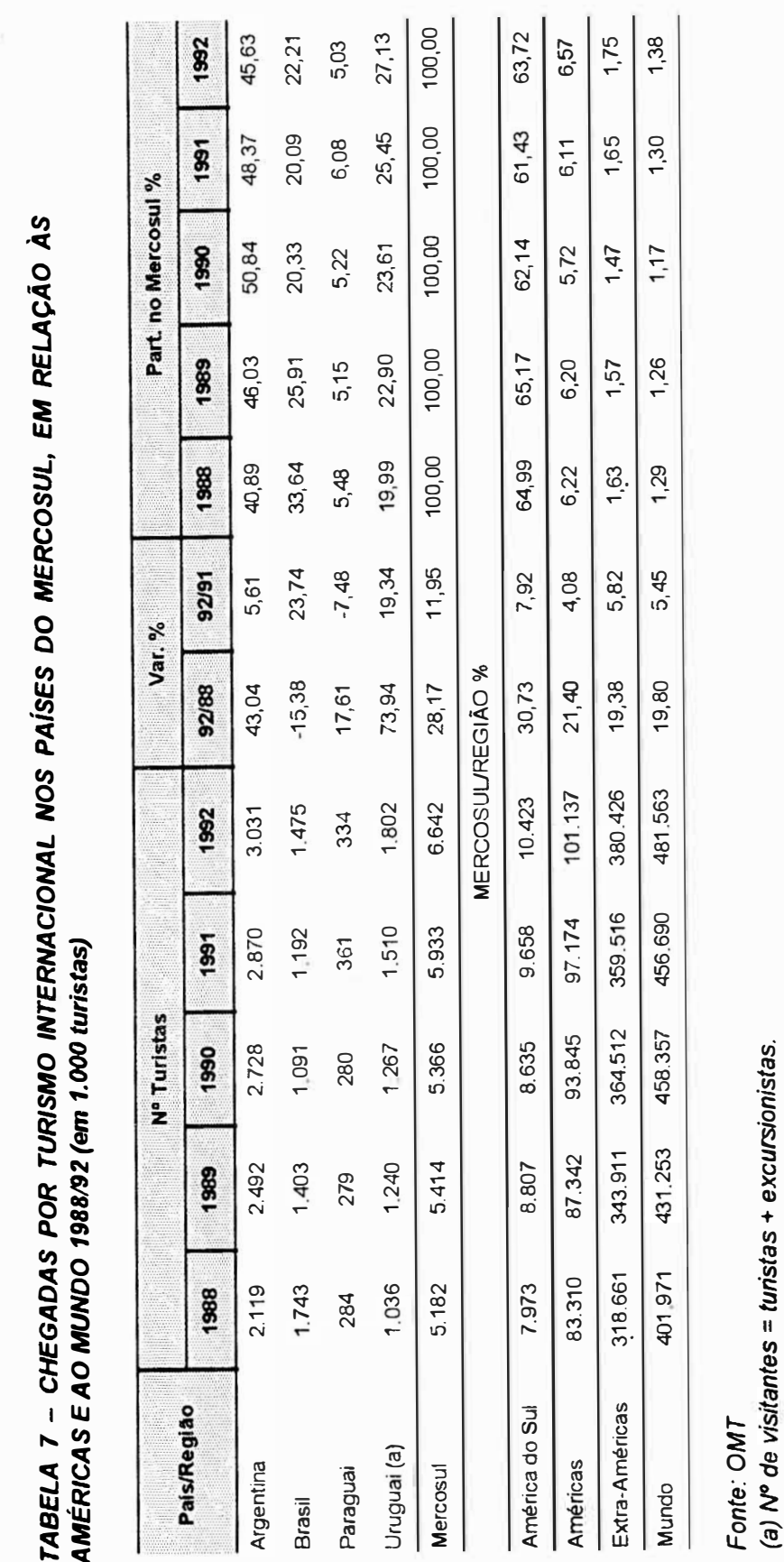


TABELA 8 - INGRESSOS POR TURISMO INTERNACIONAL NOS PAISES DO MERCOSUL, EM RELAÇÃO ÀS AMÉRICAS E AO MUNDO 1988/92 (em US\$ milhōes)

\begin{tabular}{|c|c|c|c|c|c|c|c|c|c|c|c|c|}
\hline \multirow{2}{*}{ Pais/Regiăo } & \multicolumn{5}{|c|}{ USs Milhoes } & \multicolumn{2}{|c|}{ Var. $\%$} & \multicolumn{5}{|c|}{ Part. no Mercosul \% } \\
\hline & 1988 & 1989 & 1990 & 1991 & 1992 & $92 / 88$ & 92191 & 1988 & 1989 & 1990 & 1991 & 1992 \\
\hline Argentina & $\widetilde{34}$ & 790 & 1.975 & 2.336 & 3.090 & 387,38 & 32,28 & 24,44 & 33,55 & 52,40 & 53,18 & 62,66 \\
\hline Brasil & 1.643 & 1.225 & 1.444 & 1.559 & 1.307 & $-20,45$ & $-16,16$ & 63,34 & 52,02 & 38,31 & 35,49 & 26.51 \\
\hline Paraguai & 114 & 112 & 112 & 165 & 153 & 34,21 & $-7,27$ & 4,39 & 4,76 & 2,97 & 3,76 & 3,10 \\
\hline Uruguai (a) & 203 & 228 & 238 & 333 & 381 & 87,68 & 14,41 & 7,83 & 9,68 & 6,31 & 7,58 & 7,73 \\
\hline Mercosul & 2.594 & 2.355 & 3.769 & 4.393 & 4.931 & 90,09 & 12,25 & 100,00 & 100,00 & 100,00 & 100,00 & 100,00 \\
\hline \multicolumn{13}{|c|}{ MERCOSUL/REGIĀO \% } \\
\hline América do Sul & 4.238 & 4.055 & 5.781 & 6.643 & 7.350 & 73,43 & 10,64 & 61,21 & 58,08 & 65,20 & 66,13 & 67,09 \\
\hline Américas & 50.264 & 58.806 & 69.439 & 76.624 & 83.552 & 66,23 & 9,04 & 5,16 & 4,00 & 5,43 & $5,73^{\circ}$ & 5,90 \\
\hline Extra-Américas & 149.018 & 156.124 & 190.675 & 186.587 & 214.301 & 43,81 & 14,85 & 1,74 & 1,51 & 1,98 & 2,35 & 2,30 \\
\hline Mundo & 199.282 & 214.930 & 260.114 & 263.211 & 297.853 & 49,46 & 13,16 & 1,30 & 1,10 & 1,45 & 1,67 & 1,66 \\
\hline
\end{tabular}

Fonte: OMT

(a) $\mathrm{N}^{\circ}$ de visitantes $=$ turistas + excursionistas

TABELA 9 - CHEGADAS POR TURISMO INTERNACIONAL NO BRASIL PROCEDENTES DOS PAISES DO MERCOSUL EM RELAÇÃO ÀS AMÉRICAS E AO MUNDO - 1988/92 (em 1.000 turistas)

\begin{tabular}{|c|c|c|c|c|c|c|c|c|c|c|c|c|}
\hline \multirow{2}{*}{ Pais/Regiâo } & \multicolumn{5}{|c|}{$N^{0}$ Turistas } & \multicolumn{2}{|c|}{ Var. \% } & \multicolumn{5}{|c|}{ Part. no Mercosul \% } \\
\hline & 1988 & 1989 & 1990 & 1991 & 1992 & 92288 & 9291 & 1988 & 1989 & 1990 & 1991 & 1992 \\
\hline Argentina & 353 & 450 & 264 & 406 & 598 & 69,41 & 47,29 & 51,38 & 66,18 & 61,54 & 69,17 & 72,57 \\
\hline Paraguai & 122 & 84 & 65 & 69 & 72 & $-40,98$ & 4,35 & 17,76 & 12,35 & 15,15 & 11,75 & 8,74 \\
\hline Uruguai & 212 & 146 & 100 & 112 & 154 & $-27,36$ & 37,50 & 30,86 & 21,47 & 23,31 & 19,08 & 18,69 \\
\hline Mercosul & 687 & 680 & 429 & 587 & 824 & 19,94 & 40,37 & 100,00 & 100,00 & 100,00 & 100,00 & 100,00 \\
\hline \multicolumn{13}{|c|}{ MERCOSUL/REGIĀO \% } \\
\hline América do Sul & 822 & 795 & 528 & 687 & 921 & 12,04 & 34,06 & 83,58 & 85,53 & 81,25 & 85,44 & 89,47 \\
\hline Américas & 1.115 & 980 & 682 & 828 & 1.067 & $-4,30$ & 28,86 & 61,61 & 69,39 & 62,90 & 70,89 & 77,23 \\
\hline Extra-Américas & 628 & 423 & 409 & 364 & 408 & $-35,03$ & 12,09 & 109,39 & 160,76 & 104,89 & 161,26 & 201,96 \\
\hline Mundo & 1.743 & 1.403 & 1.091 & 1.192 & 1.475 & $-15,38$ & 23,74 & 39,41 & 48,47 & 39,32 & 49,24 & 55,86 \\
\hline
\end{tabular}

Fonte: OMT 


\section{No Brasil}

Analisando-se aschegadas por turismo internacional no Brasil, procedente dos paises do Mercosul, entre 1988 e 1992, constata-se a presença mais destacad do fluxo originado da Argentina (Tabela 9). As chegadas provenientes da Argentina cresceram em 1992, 69\% em comparação com 1988 e 47\% em res da a 1991, tendo sua participação no total das chegadas do Mercosul ao Brasil elevąáa se de $51 \% \mathrm{em} 1988$ para $73 \% \mathrm{em} 1992$. O número de turistas vindos do Paraguai, caiu em $41 \%$ comparado com 1988 e cresceu $4 \%$ em relação a 1991, com sua participação nas chegadas do Mercosul ao Brasil declinando de $18 \%$ para $9 \%$ no periodo. Já o fluxo proveniente do Uruguai decresceu $27 \%$ diante do fluxo de 1988 e aumentou quase $38 \%$ comparado ao de 1991 , caindo a sua participação no total das chegadas ao Brasil provenientes do Mercosul, de $31 \%$ em 1988 para $19 \% \mathrm{em}$ 1992.

As chegadas por turismo internacional ao Brasil, originadas das regiões comparadas, observaram as seguintes variações em 1992, com relação a 1988 e 1991, respectivamente: do Mercosul, $+20 \%$ e $+40 \%$; da América do Sul, $+12 \%$ e $+34 \%$; das Américas, - $4 \%$ c $+29 \%$; da região Extra-Américas, $-35 \%$ e $+12 \%$; do Mundo, $-15 \%$ e $+24 \%$

A participação das chegadas no Brasil procedentes do Mercosul, no total das chegadas oriundas dessas regiões, situaram- se, em 1988 e 1992, respectivamente em: da América do Sul, 84 e 89\%; das Américas, 62 e 77\%; da região ExtraAméricas, superior em $9 \%$ e em 102\%; e do Mundo, 39 e $56 \%$. Esses números refletem, para o Brasil, um crescimento mais acentuado, no periodo analisando, do fluxo intra-Mercosul, em relação ao fluxo extra-regional.

\section{Na Argentina}

Para a Argentina, o país de maior peso no fluxo turístico internacional originado do Mercosul é o Uruguai, embora registrando um decréscimo da sua participação, que passou de $65 \%$ em 1988 para $62 \%$ em 1992; observa-se, nesse ano, um desempenho superior $\mathrm{em} 28 \%$, quando comparado com 1988, cinferior em $2 \%$ ao de 1991 (Tabela 10). Aschegadas de brasileiros à Argentina têm apresentado tendência de crescimento. Comparadas com 1988 e 1991, elevaram- se $\mathrm{cm} 64 \% \mathrm{e}$ $\mathrm{em}$ torno de $11 \%$, respectivamente, com a sua participação no total das chegadas do Mercosul à Argentina evoluindo de $18 \% \mathrm{em} 1988$ para quase $22 \% \mathrm{~cm}$ 1992. Já o fluxo de paraguaios na Argentina manteve uma participação estável no fluxo do Mercosul para esse pais, em torno de $17 \%$ no periodo analisado observando incrementos de $36 \%$ e $2 \%$ em 1992, cm comparação com 1988 e 1991, respectivamente.

O número de turistas proveniente das regiões comparadas para a Argentina, apresentou em 1992, variações positivas em relação a 1988 e 1991 , respectivamen-

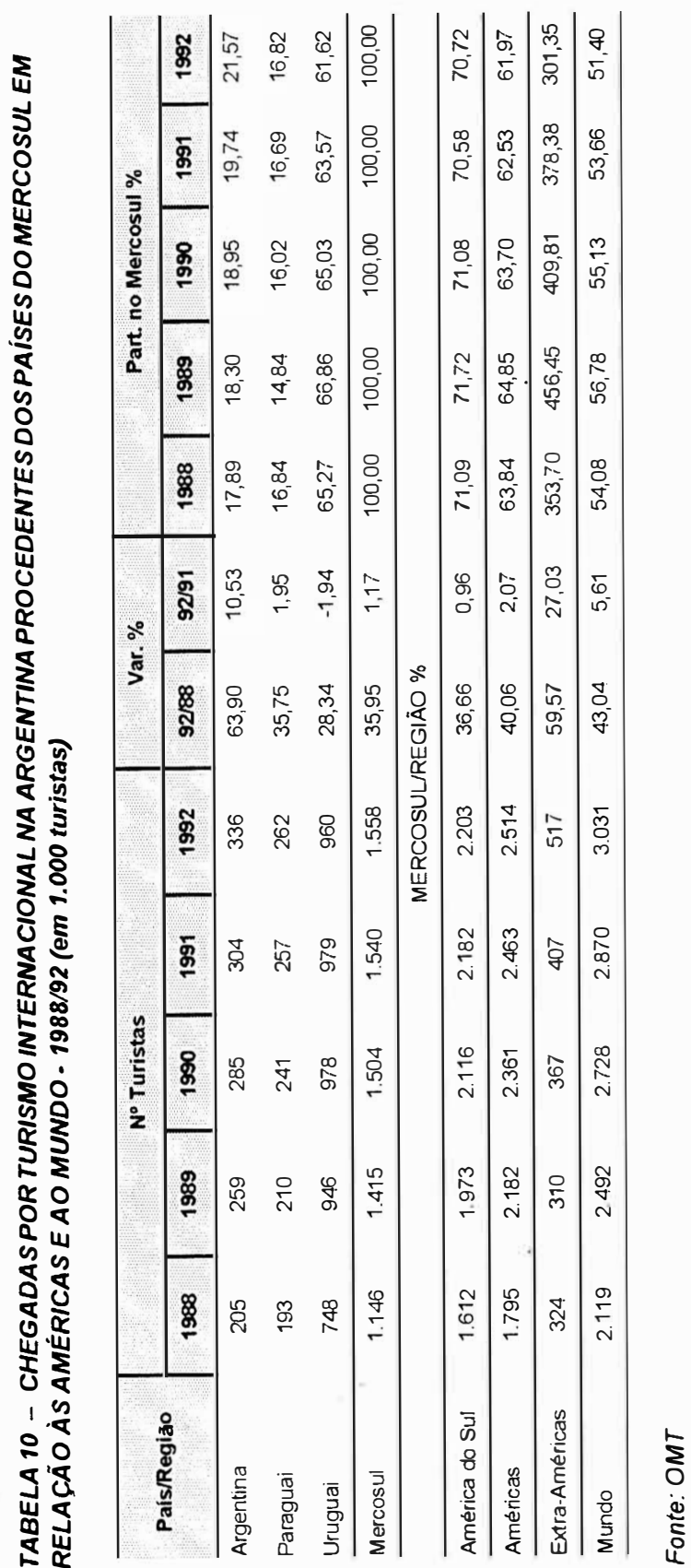


te: do Mercosul, $+36 \%$ e $+1 \%$; da América do Sul, $+37 \%$ e $+1 \%$; das Américas, $+40 \% \mathrm{e}+2 \%$; da região Extra-Américas, $+60 \% \mathrm{e}+27 \%$; e do Mundo, $+43 \% \mathrm{e}+6 \%$, As chegadas por turismo internacional à Argentina originadas $+43 \% \mathrm{e}+6 \%$. representaram em 1988 e 1992, respectivamente, cerca de $71 \%$ dos Mercosul procedentes da América do Sul, 64 e $62 \%$ das provenientes das chegadas superaram as da região Extra-Américas em 254 e $201 \%$, $51 \%$ do total mundial das chegadas a Argentina o maior peso do fluxo intra-Mercosul, comprova-se também para a Argentina o maior peso do fluxo intra-Mercosul, de modo mais significativo que para o Brasil, embora observando, no período em questão, um decréscimo do mesmo em torno de $-3 \%$

\section{No Paraguai}

A Tabela 11 apresenta a evolução das chegadas por turismo internaciona no Paraguai procedentes dos países do Mercosul, entre 1988/92. Nesse período, os argentinos responderam pela maior parcela do fluxo turístico intra-regional do Paraguai, registrando porém uma queda da sua participação, de quase $56 \% \mathrm{em} 1988$ para $53 \%$ em 1992, observando-se variações negativas em 1992, de -1\% e - $11 \%$ comparado a 1988 e 1991 , respectivamente.

A participação do Brasil no fluxo de turistas originado do Mercosul para o Paraguai, elevou- se de $34 \% \mathrm{~cm} 1988$ para cerca de $37 \% \mathrm{~cm} 1992$ apresentando crescimento de $10 \%$ c $6 \%$, nesse ano, em relaç̃o a 1988 c 1992 ,

A chegada de uruguaios ao Paraguai em relação às provenientes do Mercosul, representou no período, uma participação estabilizada $\mathrm{cm} 10 \%$, observando no ano de 1992 um crescimento de 5\% comparado a 1988 e uma queda próxima a $-28 \%$ em relação a 1991

As chegadas procedentes das regiões comparadas registrou em 1992, em relação a 1988 e 1991, as seguintes variações, respectivamente: do Mercosul, +4\% e $-8 \%$; da Am;erica do Sul, $+8 \%$ c $-9 \%$; das Américas, cerca de $+15 \%$ e $-8 \%$; da região Extra-Américas, $+32 \%$ e $-6 \%$; e do Mundo, $+18 \%$ c $-7 \%$. Nota- se 0 decréscimo do fluxo turístico internacional para o Paraguai $\mathrm{cm}$ 1992, para todas as regiões de origem do mesmo.

A participação das chegadas ao Paraguai procedentes do Mercosul, no tota do fluxo originado das regiões comparadas, situou-se, em 1988 e 1992, respectivamente em : da América do Sul, 89 e $85 \%$; das Américas, 85 c 76\%; superou as da região Extra-Américas em 296 e $210 \%$; e do Mundo, 70 e $61 \%$ Evidencia-se um substancial representatividade do fluxo turístico intra-Mercosul para 0 Paraguai(superior a $60 \%$ ), embora apresentando uma queda de 9 pontos percentuais no período, o que sinaliza um crescimento do segmento extra-regional.

\section{No Uruguai}

A situação do fluxo turístico internacional no Uruguai, originado do Mercosul, revela uma total dependência das chegadas procedentes da Argentina,

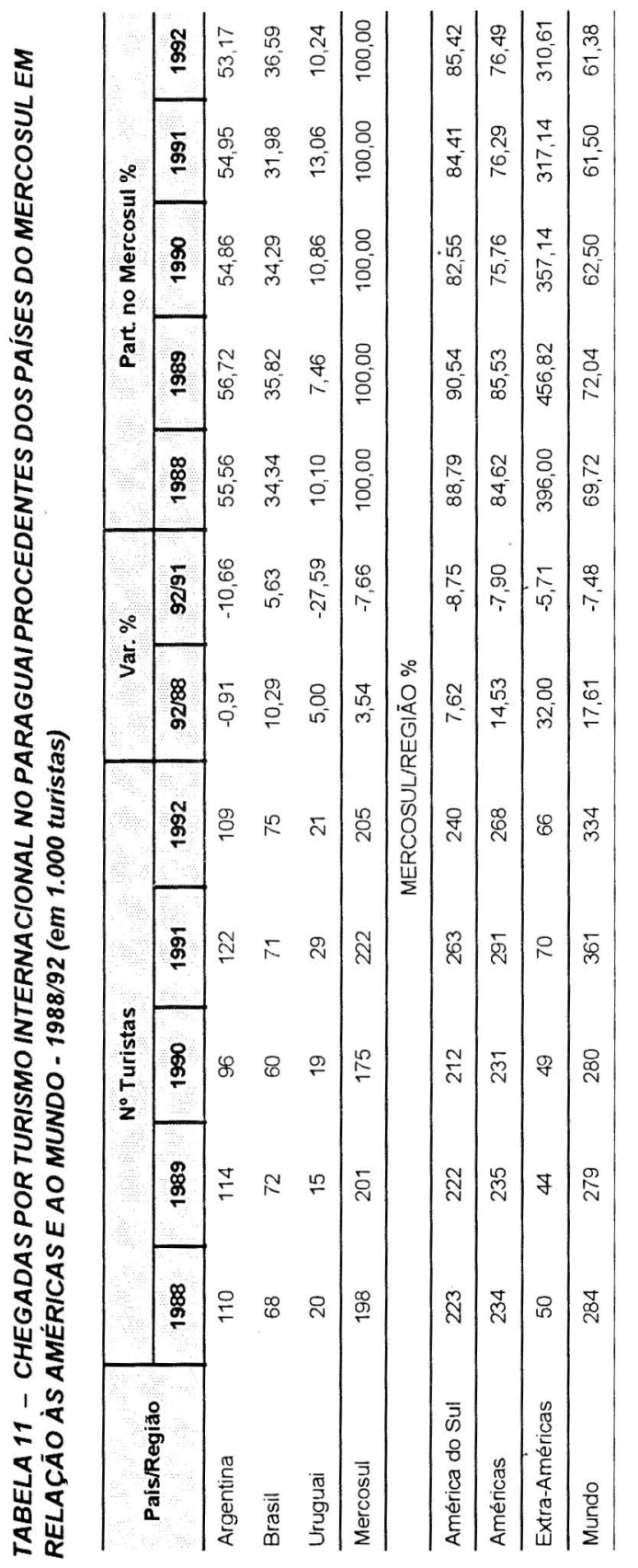




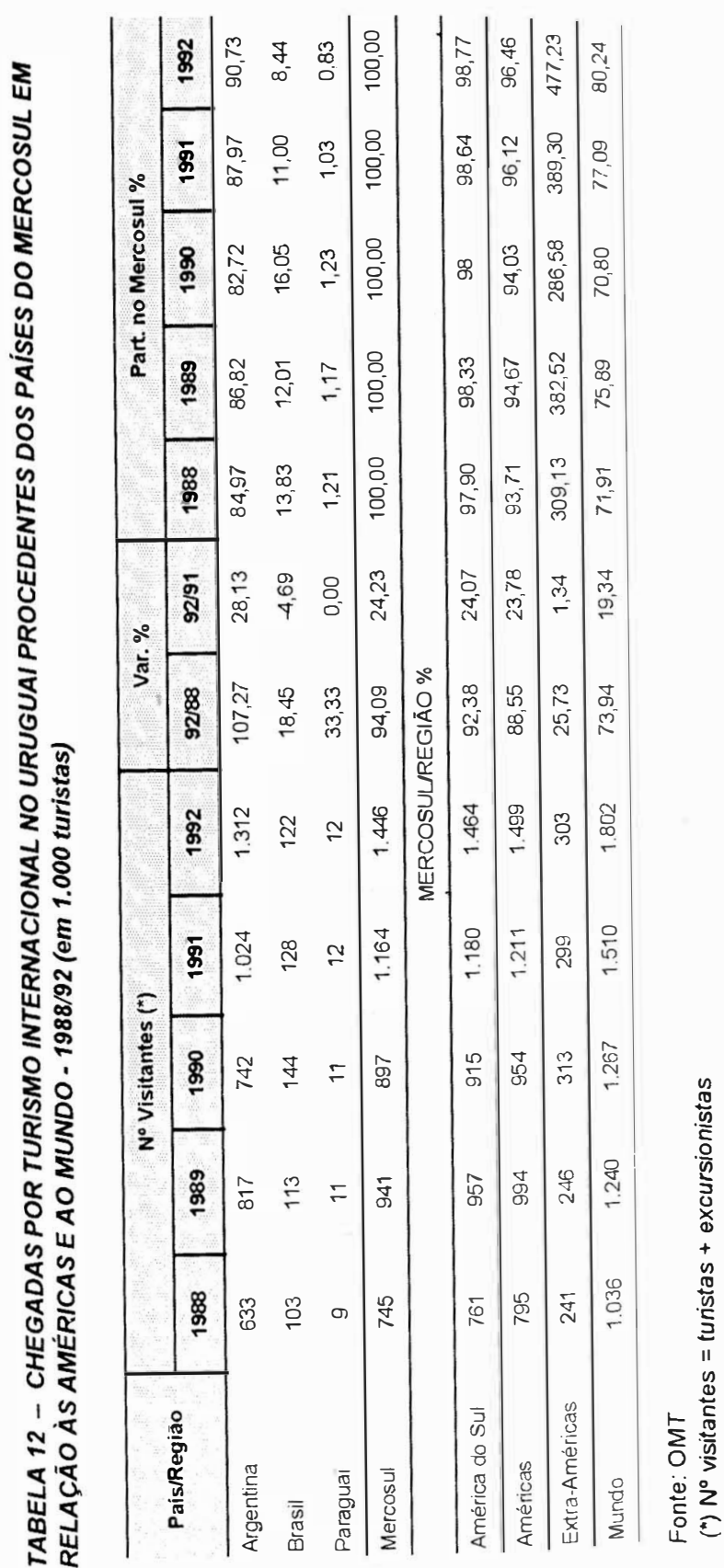

cuja participação elevou- sc de $85 \%$ em 1988 para 91\% em 1992, cxperimentando incrementos nesse ano, de $107 \%$ c de $28 \%$ em comparação com 1988 e 1991, respectivamente (Tabela 12).

A participação dos turistas brasileiros no fluxo intra-regional do Uruguai, decresceu no período, de 14 para $8 \%$, registrando em 1992 , variações de $+18 \%$ e $-5 \%$ em relação a 1988 e 1991 , respectivamente.

Já o Paraguai observou uma participação insignificante nas chegadas do Mercosul ao Unuguai, em torno de $1 \%$ no período, 'registrando- se, em 1992, crescimento de $33 \%$ em comparação com 1988, não ocorrendo variação em relação a 1991 .

O fluxo ao Unuguai originado das regiões comparadas, apresentaram em 1992, as seguintes variações relativas aos anos de 1988 e 1991, respectivamente: do Mercosul, $+94 \%$ e $+24 \%$; da América do Sul $+92 \%$ e $+24 \%$; das Américas, em torno de $+89 \%$ e de $+24 \%$; da região Extra-Américas, $+26 \%$ e $+1 \%$; e do total mundial, $+74 \mathrm{c}+19 \%$.

As chegadas por turismo internacional noUnuguai, procedentes do Mercosul, representaram, em relação ao fluxo originado das regiões comparadas, nos anos de 1988 e 1992, respectivamente: da América do Sul, 98 e 99\%; das Américas, 94 e 96\%; superaram as da região Extra-Américas em 209 e 377\%; e do Mundo, 72 e $80 \%$. Fica evidentc a importância vital do fluxo turístico intra-Mercosul para 0 Uruguai, o qual inclusive cresceu 8 pontos percentuais no período considerado.

\section{Conclusão}

Da análise do fluxo turístico intra-regional, no âmbito do Mercosul, destacam-se as seguintes constatações:

- no período analisado, Brasil e Uruguai observaram crescimento do fluxo intraregional, de 7 e 8 pontos percentuais, respectivamente, embora, entre os quatro parceiros, o Brasil seja o país onde o fluxo extra-regional alcança a maior representatividade;

- Argentina e Paraguai registraram uma perda relativa na participação do fluxo intra-regional, ocorrendo um decréscimo no período, de 3 e 9 pontos percentuais, respectivamente;

- a Argentina é o maior emissor intra-regional, respondendo em 1992 por $91 \%$, $73 \%$ e $53 \%$, do fluxo receptivo intra-Mercosul de Uruguai, Brasil e Paraguai;

- Uruguai e Paraguai apresentam uma forte dependência estrutural do fluxo turistico intra-Mercosul, com o mesmo significado em 1992, 80 e 61\%, respectivamente, do total de chegadas por turismo internacional contabilizadas nesses países. 
Desse modo, a exemplo do que ocorre em relação à economia do país e à dinâmica do seu fluxo de comércio, também no âmbito do turismo, a Argen constitui-se no alvo preferencial dos outros países-membros do mercado regional do Cone Sul. Interessa portanto, aos seus parceiros, que a Argentina mantenha um condição de estabilidade na sua economia e na paridade cambial de sua moeda inclusive com uma posição favorável à mesma no que concerne ao nivel de preços relativos, que garanta um maior poder de compra do peso argentino nos mercados internos dos seus parceiros.

Assim, no âmbito do turismo, o Mercosul ć:

- de vital interesse para o Uruguai, sobretudo, c Paraguai - pela dependência estrutural do nuxo turístico intra-Mercosul, que assume uma importância estratégica para desenvolvimento do turismo nesses países, em função do incremento esperado a partir da consolidação do processo de intcgração entre os parceiros do Conc Sul

- de grande interesse para a Argentina, em razão do grande potencial dos seus atrativos e da diversificação da sua oferta turistica com capacidade para absorver o crescimento esperado do fluxo turístico intra-Mercosul;

- de relativo interesse para o Brasil, no curto prazo, devido aos problemas de imagem e qualidade do seu produto turístico no mercado internacional, e às restrições e dificuldades estruturais, além da incertcza, quanto à continuidade e preservação do quadro de estabilidade da sua cconomia c mocda.

O advento do Plano Real, com a valorização da moeda brasileira cm relação ao dólar americano c também ao peso argentino, provocando uma perda relativa do poder de compra dessas moedas no mercado interno de bens e serviços, sinaliza o risco concreto de queda no fluxo turístico intra-Mercosul para o Brasil, repercutindo negativamente no volume dos ingressos por turismo internacional

Superados csses aspectos e limitações, o Mercosul, em termos turísticos, tornar-se-á de grande intcresse para o Brasil, com a esperada elevação do fluxo turístico intra-regional podendo ancorar o desenvolvimento do turismo no país como resultante da livre circulação cconômica de um expressivo número de viajantes e da geração de riqueza decorrente da distribuição de bens c senviços por eles efetivada.

\section{Bibliografia}

DRUCKER, Peter F. 1992. Administrando para o futuro. São Paulo: Pioneira. EMBRATUR. 1993. Dados econômicos do turismo brasileiro. Brasilia: Embratur. MERC()SUI, 1994. Ata da A'A reunião especializada de turismo do Mercosul. San Juan, 9 e 10 ago. MILONE, Paulo C. 1993. A importância do turismo no Mercosul. São Paulo (mimeo.)

NAISIIIT'T, Jolun. 1994. Paradoxo global. Rio de Janeiro: Campus.
OMT. 1993. Previsiones del turismo mundial hasta el año 2000 y después. Madrid: OMT. Anuario de estadisticas del turismo $46^{2}$ ed Madrid: OMT, vi e il.

1994. Compendio de estadisticas del turismo. 1988-1992. $14^{3}$ ed. Madrid: OMT. Tendencias del mercado turistico. Americas. 1980-1993. Madri: OMT, 1994. 1994. Turismo internacional en las Americas - 1970 - 1993. Madrid: OMT

ROMERA Alex C. s. d. Turismo do Nordeste no âmbito do Mercosul Brasilia (mimeo).

Reflexiones desde una perspectiva integradora. Bueno Aires: Docencia.

TACHINARDI, Maria H. 1994. Criação de órgãos do Mercosul será ratificada na Conferência de Brasilia Gazeta Mercantil. Salvador, 1 nov.

TRIGUEIROS JÚNIOR, Oswaldo 1994. Novos numos do turismo Jornal do Brasil Rio de Janeiro, 11

YASOSHIMA, José R. 1993. O turismo e as normas ISO série 9000. São Paulo (mimeo) 